Check for updates

Cite this: RSC Adv., 2017, 7, 23122

\title{
Electrospinning synthesis of $\mathrm{CO}_{3} \mathrm{O}_{4} \mathrm{OC}$ nanofibers as a high-performance anode for sodium ion batteries $\uparrow$
}

\begin{abstract}
Zhenwei Mao, Min Zhou, ${ }^{*}$ Kangli Wang, Wei Wang, Hongwei Tao and Kai Jiang (D)*
A unique 1D structure of $\mathrm{CO}_{3} \mathrm{O}_{4}$ nanoparticles encapsulated in carbon nanofibers has been fabricated by a facile, cost-effective and scalable electrospinning method followed by a two-step heat-treatment. When tested as an anode for sodium ion batteries, the composite exhibits an initial discharge and charge capacity of $768.4 \mathrm{~mA} \mathrm{~h} \mathrm{~g}^{-1}$ and $422.4 \mathrm{~mA} \mathrm{~h} \mathrm{~g}^{-1}$ at $50 \mathrm{~mA} \mathrm{~g}^{-1}$, and retains a reversible specific capacity of $\sim 300 \mathrm{~mA} \mathrm{~h} \mathrm{~g}^{-1}$ up to 100 cycles. At a higher current density of $500 \mathrm{~mA} \mathrm{~g}^{-1}$, a reversible capacity of $251.7 \mathrm{~mA} \mathrm{~h} \mathrm{~g}^{-1}$ is still obtained. Meanwhile, compared to the pure $\mathrm{CO}_{3} \mathrm{O}_{4}$ nanofibers, $\mathrm{Co}_{3} \mathrm{O}_{4}(\mathrm{aC}$ nanofibers demonstrate much improved capacity retention of $84.3 \%$ over 500 cycles. The good electrochemical performance is mainly attributed to the unique 1D nanofiber structure with stable structural integrity and improved electrical conductivity rendered by the carbon nanofiber framework, which is more convenient for the electron transport and $\mathrm{Na}^{+}$insertion/extraction of the active materials.
\end{abstract}

Received 12th March 2017 Accepted 18th April 2017

DOI: $10.1039 / \mathrm{c} 7 \mathrm{ra02965a}$

rsc.li/rsc-advances in the Na-storage cathode field, varieties of Na storage materials have been reported to demonstrate certain Na-storage capacity and cycling performances, such as layered transition metal oxides, phosphates, Prussian blue analogues, organic cathodes and so on..$^{9-14}$ In the case of anode materials, transitional metal oxides (TMOs) are considered to be promising anode materials for sodium ion batteries due to their resource abundance, low cost and high theoretical capacity (1005, 889, 718, 674 and 661 $\mathrm{mA} \mathrm{h} \mathrm{g}{ }^{-1}$ for $\mathrm{Fe}_{2} \mathrm{O}_{3}, \mathrm{Co}_{3} \mathrm{O}_{4}, \mathrm{NiO}, \mathrm{CuO}$ and $\mathrm{ZnO}$, respectively). Nevertheless, transitional metal oxides usually suffer from serious volume expansion during cycling. In addition, the poor conductivity of TMOs lead to inferior capacity utilization, poor cycling stability and poor rate capability. Recent researches show that the electrochemical performance of TMOs electrode strongly depend on the structure and pore size of the particles. ${ }^{15-17}$ As a result, great efforts have been devoted to design specific structures, such as hollow spheres, core-shell structure, nanotubes and so on. ${ }^{18-23}$ Lu et al. synthesized micronanostructured $\mathrm{CuO} / \mathrm{C}$ spheres by aerosol spray pyrolysis, delivering a capacity of $402 \mathrm{~mA} \mathrm{~h} \mathrm{~g}^{-1}$ after 600 cycles at a current density of $200 \mathrm{~mA} \mathrm{~g}^{-1} \cdot{ }^{21}$ Another effective strategy is to incorporate various conductive matrix to the nanostructured TMOs, thus improving the electronic conductivity as well as relieving the volume expansion during repeated cycling. ${ }^{18-23}$ Jian et al. synthesized $\mathrm{Fe}_{2} \mathrm{O}_{3}$ nanocrystals@GNS by coating graphene nanosheets (GNS) on $\mathrm{Fe}_{2} \mathrm{O}_{3}$ nanocrystals. The discharge-charge capacity delivered by $\mathrm{Fe}_{2} \mathrm{O}_{3}$ @GNS reaches $400 \mathrm{~mA} \mathrm{~h} \mathrm{~g}{ }^{-1}$ over 200 cycles and no capacity decay can be observed. ${ }^{18}$

One dimensional nanostructures such as nanotubes, nanowires, nanorods and nanofibers are considered as ideal structure for Na-storage due to their uniform structure which possess 
high electronic and ionic conductivities as well as strong tolerance to resist structural pulverization, leading to great enhancement of the electrochemical performances. ${ }^{21,22}$ Electrospinning is a versatile, low-cost and scalable method to fabricate $1 \mathrm{D}$ nanofibers. $\mathrm{Co}_{3} \mathrm{O}_{4}$ is widely considered as promising anode materials for both LIBs and SIBs based on its relatively high conductivity and high theoretical capacity (889 $\mathrm{mA} \mathrm{h} \mathrm{g}^{-1}$ ). In this work, we fabricated a unique 1D structure carbon coated $\mathrm{Co}_{3} \mathrm{O}_{4}$ with the structure of $\mathrm{Co}_{3} \mathrm{O}_{4}$ nanoparticles uniformly wrapped in carbon nanofibers (denoted as $\mathrm{Co}_{3} \mathrm{O}_{4}$ @CNFs) by a facile electrospinning technique followed by a twostep heat-treatment. The unique 1D carbon framework can not only buffer the volume variation of $\mathrm{Co}_{3} \mathrm{O}_{4}$ nanoparticles, but also serves as the electron and ion pathways to improve the conductivity of the composite. The as prepared $\mathrm{Co}_{3} \mathrm{O}_{4} @ \mathrm{CNFs}$ composites demonstrate great enhancement in electrochemical performances with high reversible capacity of $422.4 \mathrm{~mA} \mathrm{~h} \mathrm{~g}^{-1}$ and cycling stability over 500 cycles.

\section{Experimental}

\section{Synthesis of $\mathrm{Co}_{3} \mathrm{O}_{4} @ \mathrm{C}$ nanofibers composite}

Polyacrylonitrile (PAN, MW = 150 000) was purchased from Sigma-Aldrich. Cobalt(II) acetate tetrahydrate (CoAc, >99.9\%) and $N, N$-dimethylformamide (DMF, 99.8\%) were purchased from Sinopharm and used as received without any purified.

In a typical process, $0.6 \mathrm{~g}$ CoAc was added into $10 \mathrm{~mL} \mathrm{DMF}$ and stirred for a few minutes to dissolve. After that, $1 \mathrm{~g}$ PAN was slowly added into the above solution and stirred continuously at $80{ }^{\circ} \mathrm{C}$ for $6 \mathrm{~h}$ to yield a homogeneous solution. The prepared homogeneous solution was then loaded into a plastic syringes $(10 \mathrm{~mL})$ with a needle of $20 \mathrm{G}$ and then placed on a commercial electrospinning setup (Ucalery, Beijing). The collector to the needle distance was kept constant at $15 \mathrm{~cm}$ to collect a light-pink film on an aluminium foil wrapped around a drum collector rotating at a speed of $0.6 \mathrm{~m} \mathrm{~min}^{-1}$. A positive high-voltage power of $12 \mathrm{kV}$ was applied to the needle tip, and a negative high-voltage power of $3 \mathrm{kV}$ was applied to the collecting drum. The flow rate of fluid was set to be $0.8 \mathrm{~mL} \mathrm{~h}^{-1}$. The humidity level inside the electrospinning chamber was $40 \%$, and the temperature was around $30{ }^{\circ} \mathrm{C}$. The as-spun CoAc-PAN nanofibers composite film was first stabilized at $280{ }^{\circ} \mathrm{C}$ for $90 \mathrm{~min}$ in air. Then the as-stabilized film was carbonized at $650{ }^{\circ} \mathrm{C}$ for $1 \mathrm{~h}$ in argon atmosphere. Finally, the carbonized film was oxidized at $300{ }^{\circ} \mathrm{C}$ for $30 \mathrm{~min}$. The heating rate was set to be $3{ }^{\circ} \mathrm{C} \min ^{-1}$. Other different amount of CoAc was added to the precursor solution respectively to determine the optimized carbon content of the composite, and the obtained composites were labelled as $\mathrm{Co}_{3} \mathrm{O}_{4}$ @CNFs-2 and $\mathrm{Co}_{3}$ $\mathrm{O}_{4}$ @CNFs-3. In order to identify the optimized carbonization temperature, different carbonized temperature were set, namely, $550{ }^{\circ} \mathrm{C}, 600{ }^{\circ} \mathrm{C}, 650{ }^{\circ} \mathrm{C}$ and $750{ }^{\circ} \mathrm{C}$. The obtained composites were denoted as $\mathrm{Co}_{3} \mathrm{O}_{4} @ \mathrm{CNF}-550, \mathrm{Co}_{3} \mathrm{O}_{4} @ \mathrm{CNF}-$ 600, $\mathrm{Co}_{3} \mathrm{O}_{4} @ \mathrm{CNF}-650$ and $\mathrm{Co}_{3} \mathrm{O}_{4} @ \mathrm{CNF}-750$. In this paper, $\mathrm{Co}_{3} \mathrm{O}_{4} @ \mathrm{CNFs}$ without suffix correspond to the composite carbonized at $650{ }^{\circ} \mathrm{C}$.

\section{Synthesis of $\mathrm{Co}_{3} \mathrm{O}_{4}$ nanofibers}

Pure $\mathrm{Co}_{3} \mathrm{O}_{4}$ nanofibers (denoted as $\mathrm{Co}_{3} \mathrm{O}_{4}$ NFs) were also prepared by electrospinning for comparison. The synthesis process was almost the same with $\mathrm{Co}_{3} \mathrm{O}_{4} @ \mathrm{C}$ nanofibers composite except the $650{ }^{\circ} \mathrm{C}$ heat-treatment in air for $2 \mathrm{~h}$ after stabilizing the film in air to burn the carbon.

\section{Synthesis of carbon nanofibers}

Pure carbon nanofibers (denoted as CNFs) were synthesized by electrospinning $10 \mathrm{wt} \%$ PAN solution without adding CoAc. The electrospinning process and heat-treatment condition were the same with those of $\mathrm{Co}_{3} \mathrm{O}_{4} @ \mathrm{C}$ nanofibers composite.

\section{Characterization}

The crystal structure of the composites was characterized by Xray diffraction system (XRD-7000S) equipped with $\mathrm{Cu} \mathrm{K} \alpha$ radiation between $10^{\circ}$ and $80^{\circ}$. The morphological features were examined with a field-emission scanning electron microscope (FE-SEM, JEOL-7600F). Particle morphology of the synthesized composites was observed with transmission electron microscopy (TEM, JEOL-2100). X-Ray photoelectron spectroscopy (XPS, AXIS-ULTRA DLD-600W) was employed to evaluate the surface chemistry of materials. Thermogravimetric analysis (TGA) was conducted (TGA/DSC, Netzsch-STA 449F5) in air over a temperature range of $30-800{ }^{\circ} \mathrm{C}$ at a heating rate of $10{ }^{\circ} \mathrm{C} \mathrm{min}^{-1}$. The surface area was determined by nitrogen adsorption/desorption using the Brunauer-Emmett-Teller method (BET, Micromeritics Tristar 2000). The sample was degassed under nitrogen gas at $180{ }^{\circ} \mathrm{C}$ for a whole night prior to BET measurements.

\section{Electrochemical measurements}

All the electrochemical studies were conducted using CR2025 coin cells. The anodes were prepared by mixing the active materials $\left(\mathrm{Co}_{3} \mathrm{O}_{4} @ \mathrm{CNFs}, \mathrm{Co}_{3} \mathrm{O}_{4}\right.$ NFs, CNFs), the conductive additives (super $\mathrm{P}$ ) and the binder (carboxymethyl cellulose) in a mass ratio of $80: 10: 10$. The mixture was prepared as slurry and spread onto copper foil. The electrode was dried under vacuum at $120{ }^{\circ} \mathrm{C}$ for a whole night to remove the solvent before pressing. Then the electrodes were cut into disks $(11 \mathrm{~mm}$ in diameters) to be used as the working electrodes, sodium metal foil as a counter electrode, and a glass microporous fiber filter (Whatman, cat. no. 1825-047) as a separator, $1 \mathrm{M} \mathrm{NaClO}_{4}$ in propylene carbonate (PC) with $2 \%$ FEC (fluoroethylene carbonate) additive as the electrolyte. Assembled cells were allowed to soak overnight. The cyclic voltammetry (CV) tests were performed between $0.01 \mathrm{~V}$ and $3.0 \mathrm{~V}$ at a scan rate of $0.1 \mathrm{mV} \mathrm{s}^{-1}$ on an electrochemical workstation (CHI660c), and the galvanostatic discharge-charge cycling of the cells was carried out at different current densities between potentials of $0.01 \mathrm{~V}$ and $3.0 \mathrm{~V}$ on a battery tester (LAND $2001 \mathrm{CT}$ ) at room temperature. Electrochemical impedance spectroscopy (EIS) was carried out by applying an AC voltage of $5 \mathrm{mV}$ in the frequency range of $100 \mathrm{kHz}$ to $0.1 \mathrm{~Hz}$ on an electrochemical workstation (CHI660c). 


\section{Results and discussions}

Carbon coated $\mathrm{Co}_{3} \mathrm{O}_{4}$ nanofibers were synthesized via a singlenozzle electrospinning technique using PAN as the carbon source. For comparison, pure $\mathrm{Co}_{3} \mathrm{O}_{4}$ nanofibers (denoted as $\mathrm{Co}_{3} \mathrm{O}_{4} \mathrm{NFs}$ ) were prepared in the same way except for annealing in air to burn the carbon. During the followed stabilization process, PAN was converted to aromatic cyclized ladder type structure by cyclization, dehydrogenation, aromatization and crosslinking. ${ }^{24,25}$ After carbonization, the stabilized composite was transformed to $\mathrm{Co}_{3} \mathrm{O}_{4} @ \mathrm{CNFs}$. The $\mathrm{Co}_{3} \mathrm{O}_{4} @ \mathrm{CNFs}$ composites carbonized at different temperatures are denoted as $\mathrm{Co}_{3}$ $\mathrm{O}_{4} @ C N F-550, \quad \mathrm{Co}_{3} \mathrm{O}_{4} @$ CNF-600, $\quad \mathrm{Co}_{3} \mathrm{O}_{4} @$ CNF-650 and $\mathrm{Co}_{3} \mathrm{O}_{4} @ \mathrm{CNF}-750$. In the following text, the samples denoted as $\mathrm{Co}_{3} \mathrm{O}_{4} @ \mathrm{CNFs}$ correspond to the composite carbonized at $650{ }^{\circ} \mathrm{C}$.

The crystal structure and phase characterizations of both the $\mathrm{Co}_{3} \mathrm{O}_{4} @ \mathrm{CNFs}$ and $\mathrm{Co}_{3} \mathrm{O}_{4}$ NFs were conducted by XRD as shown in Fig. 1(a). All the diffraction peaks in Fig. 1(a) can be assigned to (111), (220), (311), (222), (400), (311), (422), (511) and (440) planes of cubic $\mathrm{Co}_{3} \mathrm{O}_{4}$ phase [(JCPDS no. 78-1970), space group $F d \overline{3} m$ (no. 227)]. The high peak intensity indicates that the material was highly crystallized after annealing at $650{ }^{\circ} \mathrm{C}$. No peaks of any other phases were detected, demonstrating the high purity of the as-prepared sample. $\mathrm{N}_{2}$ adsorption and desorption isotherm measurements were carried out to examine the specific surface area and pore size of $\mathrm{Co}_{3} \mathrm{O}_{4} @ \mathrm{CNFs}$ and $\mathrm{Co}_{3} \mathrm{O}_{4}$ NFs. As shown in Fig. 1(b), the BET surface area and average pore size of $\mathrm{Co}_{3} \mathrm{O}_{4}$ @CNFs are calculated to be $14.19 \mathrm{~m}^{2}$ $\mathrm{g}^{-1}$ and $5.6 \mathrm{~nm}$, respectively. In addition, the specific surface area and pore size of $\mathrm{Co}_{3} \mathrm{O}_{4} \mathrm{NFs}$ are $5.80 \mathrm{~m}^{2} \mathrm{~g}^{-1}$ and $4.4 \mathrm{~nm}$, respectively.

The chemical state and molecular environment of the as prepared $\mathrm{Co}_{3} \mathrm{O}_{4} @ \mathrm{CNFs}$ was evaluated by X-ray photoelectron spectroscopy (XPS). The survey spectra of the $\mathrm{Co}_{3} \mathrm{O}_{4} @ \mathrm{CNFs}$ (Fig. 1(c)) confirms the existence of Co, O, C and N. Fig. 1(d) displays the high resolution spectrum of Co. There are two
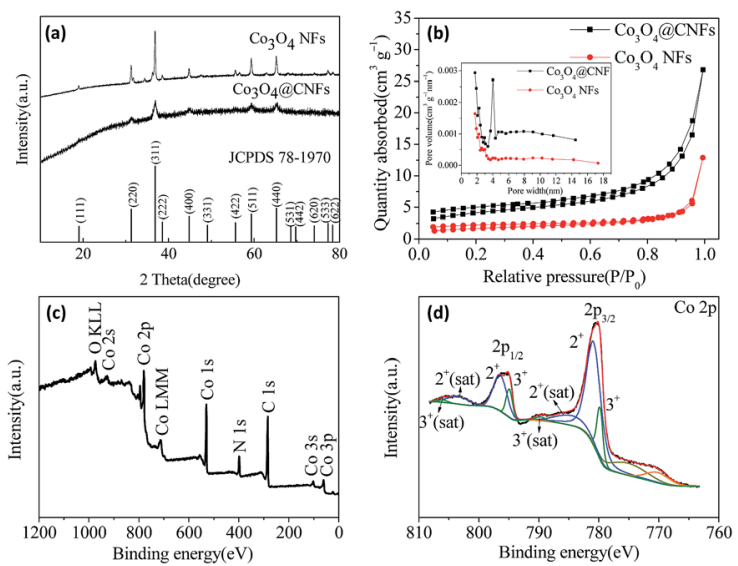

Fig. 1 (a) XRD patterns of $\mathrm{CO}_{3} \mathrm{O}_{4} \mathrm{NFs}$ and $\mathrm{CO}_{3} \mathrm{O}_{4}$ (aCNFs; (b) nitrogen adsorption-desorption isotherm for $\mathrm{CO}_{3} \mathrm{O}_{4} \mathrm{QCNFs}$ and $\mathrm{Co}_{3} \mathrm{O}_{4} \mathrm{NFs}$; (c) XPS survey spectra of $\mathrm{CO}_{3} \mathrm{O}_{4}$ (aCNFs composite; (d) deconvoluted XPS spectrum of Co $2 \mathrm{p}$. binding energy peaks located at $795.6 \mathrm{eV}$ and $780.2 \mathrm{eV}$ corresponding to the electronic states of Co $2 \mathrm{p}_{1 / 2}$ and Co $2 \mathrm{p}_{3 / 2}$ respectively with a spin-energy separation of $15.4 \mathrm{eV}$, which is the characteristic of the $\mathrm{Co}_{3} \mathrm{O}_{4}$ phase. ${ }^{23,26-28}$

The morphology of the as prepared $\mathrm{Co}_{3} \mathrm{O}_{4} @ \mathrm{CNFs}$ and $\mathrm{Co}_{3} \mathrm{O}_{4}$ NFs were characterized by FESEM. As shown in Fig. 2(a and b), the as prepared $\mathrm{Co}_{3} \mathrm{O}_{4} @ \mathrm{CNFs}$ composite emerges as smooth nanofibers with uniformly distributed diameters ranging from 150-350 nm. In contrast, the $\mathrm{Co}_{3} \mathrm{O}_{4} \mathrm{NFs}$ shows much rougher surface with the aggregation of the $\mathrm{Co}_{3} \mathrm{O}_{4}$ nanoparticles (Fig. 2(c and d)). The microstructure of $\mathrm{Co}_{3} \mathrm{O}_{4} @ C N F s$ composite was further examined by TEM. Fig. 2(e) displays the microstructure of a single $\mathrm{Co}_{3} \mathrm{O}_{4} @ \mathrm{C}$ nanofiber. As can be seen from the Fig. 2(e), the $\mathrm{Co}_{3} \mathrm{O}_{4}$ nanoparticles are uniformly embedded in the carbon nanofiber matrix. The high-resolution TEM image reveals the lattice fringes with an interplanar spacing of $0.21 \mathrm{~nm}$, corresponding to the (222) plane of $\mathrm{Co}_{3} \mathrm{O}_{4}$ nanoparticles, which are well consistent with the XRD results.

Cyclic voltammograms (CVs) of the electrodes were measured at a scan rate of $0.1 \mathrm{mV} \mathrm{s}^{-1}$ in the potential range of $0.01-3.0 \mathrm{~V}\left(v s . \mathrm{Na}^{+} / \mathrm{Na}\right)$ at room temperature. Fig. 3(a) displays the $\mathrm{CV}$ curves of the first three cycles for $\mathrm{Co}_{3} \mathrm{O}_{4} @ \mathrm{CNFs}$. In the first cycle, there is a sharp cathodic peak at $\sim 0.40 \mathrm{~V}$, which can be ascribed to the electrochemical reduction (sodiation) reaction of $\mathrm{Co}_{3} \mathrm{O}_{4}$ with $\mathrm{Na}$ to metallic $\mathrm{Co}$, the formation of $\mathrm{Na}_{2} \mathrm{O}$ and a partially irreversible solid electrolyte interphase (SEI) layer. In the anodic scan, the anodic peak at around $0.87 \mathrm{~V}$ and $1.25 \mathrm{~V}$ is

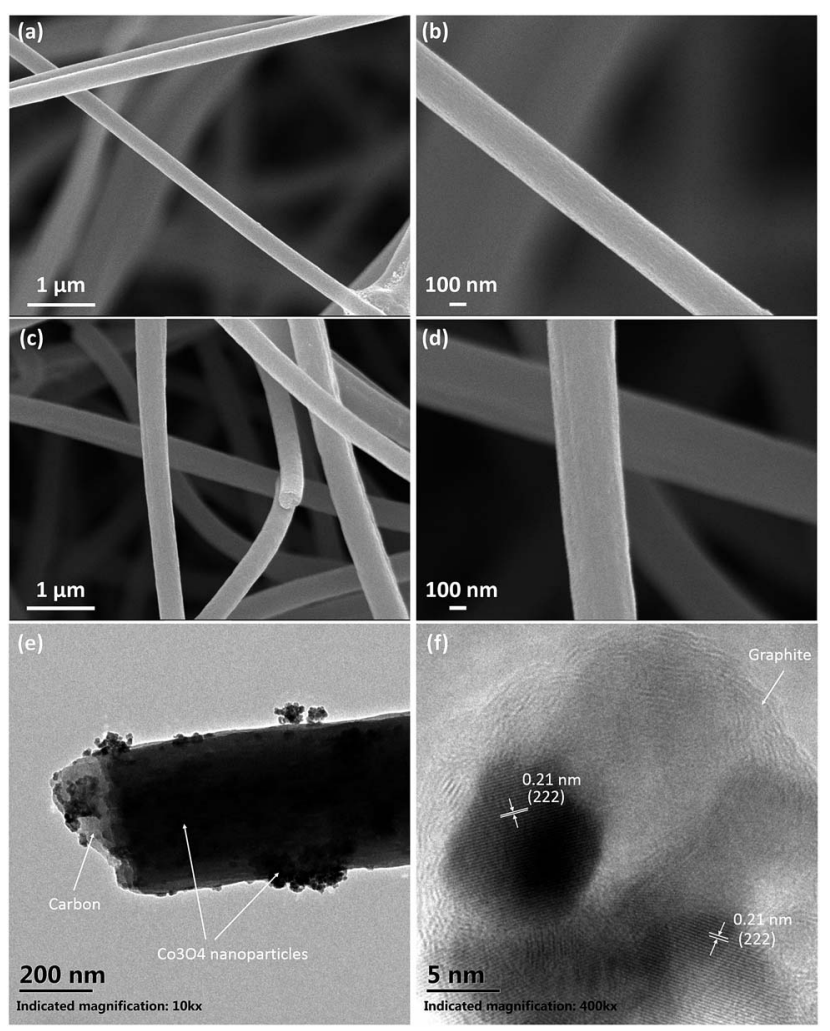

Fig. 2 (a and b) SEM images of the $\mathrm{CO}_{3} \mathrm{O}_{4}$ NFs nanofibers; (c and d) SEM images of the $\mathrm{CO}_{3} \mathrm{O}_{4}$ (aCNFs; (e) TEM image of $\mathrm{CO}_{3} \mathrm{O}_{4}$ (aCNFs; ( $f$ ) HRTEM image of $\mathrm{CO}_{3} \mathrm{O}_{4}$ @CNFs. 

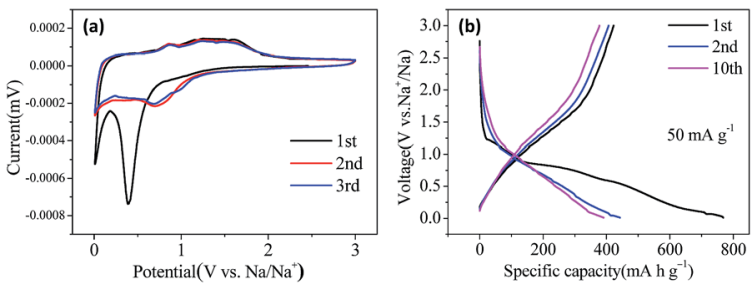

Fig. 3 (a) Cyclic voltammogram (CV) of $\mathrm{CO}_{3} \mathrm{O}_{4}$ @CNFs at a scan rate of $0.1 \mathrm{mV} \mathrm{s}^{-1}$ between $0.01 \mathrm{~V}$ and $3.0 \mathrm{~V}$ for the first three cycles; (b) galvanostatic charge/discharge curves of $\mathrm{CO}_{3} \mathrm{O}_{4} \mathrm{aCNFs}$ for the $1^{\text {st }}, 2^{\text {nd }}$ and $10^{\text {th }}$ cycles between $0.01-3.0 \mathrm{~V}$ versus $\mathrm{Na}^{+} / \mathrm{Na}$ at a current density of $50 \mathrm{~mA} \mathrm{~g}^{-1}$.

ascribed to the oxidation (desodiation) reaction of $\mathrm{Co}_{3} \mathrm{O}_{4}$. The formation of $\mathrm{Co}$ and $\mathrm{Na}_{2} \mathrm{O}$ and the reformation of $\mathrm{Co}_{3} \mathrm{O}_{4}$ can be described by the following electrochemical conversion reaction. ${ }^{23}$ In the subsequent cycles, the cathodic peak shifts to $0.70 \mathrm{~V}$. The peaks intensity and the integral areas of the next cycle is very close to those of the second cycle. These results show that the electrochemical reversibility of the $\mathrm{Co}_{3} \mathrm{O}_{4} @ \mathrm{CNFs}$ is gradually improved after the first cycle. The $\mathrm{CV}$ curves of the $\mathrm{Co}_{3} \mathrm{O}_{4}$ NFs (Fig. S5 $\dagger$ ) are very similar to those of $\mathrm{Co}_{3} \mathrm{O}_{4} @ \mathrm{CNFs}$, except for a little shift of the peak location, suggesting the similar reaction mechanism as below.

$$
\mathrm{Co}_{3} \mathrm{O}_{4}+8 \mathrm{Na}^{+}+8 \mathrm{e}^{-} \leftrightarrow 4 \mathrm{Na}_{2} \mathrm{O}+3 \mathrm{Co}
$$

To evaluate the electrochemical performance of the $\mathrm{Co}_{3}$ $\mathrm{O}_{4} @$ CNFs composite for SIBs applications, the galvanostatic charge and discharge measurements of the assembled cells were performed at the current density of $50 \mathrm{~mA} \mathrm{~g}^{-1}$ in the voltage range of $0.01-3.0 \mathrm{~V}$ (versus $\mathrm{Na}^{+} / \mathrm{Na}$ ). As shown in Fig. 3(b), in accordance with the CV curves, the $\mathrm{Co}_{3} \mathrm{O}_{4} @ \mathrm{CNFs}$ demonstrate a charge/discharge plateau at about $0.75 \mathrm{~V}$ in the first cycle, which gradually disappears in the subsequent cycles. The initial discharge and charge capacities are $768.4 \mathrm{~mA} \mathrm{~h} \mathrm{~g}^{-1}$ and $422.4 \mathrm{~mA} \mathrm{~h} \mathrm{~g}{ }^{-1}$, corresponding to the initial coulombic efficiency of about $55 \%$. The irreversible capacity loss arising during the first cycle is due to the incomplete conversion reaction and the formation of SEI layer caused by the irreversible decomposition of the electrolyte and other side effects. The reversible capacities of the $\mathrm{Co}_{3} \mathrm{O}_{4}$ @CNFs remain at about 400

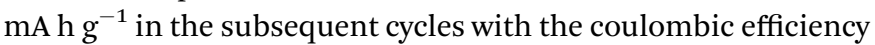
quickly increasing to over $95 \%$.

In order to evaluate the electrochemical performances of the $\mathrm{Co}_{3} \mathrm{O}_{4} @ \mathrm{CNFs}$ carbonized at different temperatures, the cycling performance of the $\mathrm{Co}_{3} \mathrm{O}_{4} @ \mathrm{CNF}-550, \mathrm{Co}_{3} \mathrm{O}_{4} @ \mathrm{CNF}-600, \mathrm{Co}_{3}-$ $\mathrm{O}_{4} @ \mathrm{CNF}-650$ and $\mathrm{Co}_{3} \mathrm{O}_{4} @ \mathrm{CNF}-750$ was conducted at a current density of $100 \mathrm{~mA} \mathrm{~g}^{-1}$, as shown in Fig. S6. $\dagger$ The initial discharge and charge capacities of the above-mentioned composites are 492.6/294.7 $\mathrm{mA} \mathrm{h} \mathrm{g}^{-1}, 533.9 / 324.6 \mathrm{~mA} \mathrm{~h} \mathrm{~g}^{-1}$, 768.4/422.4 $\mathrm{mA} \mathrm{h} \mathrm{g}^{-1}$ and 651.1/331.5 $\mathrm{mA} \mathrm{h} \mathrm{g}^{-1}$, respectively. After 50 cycles, the composite carbonized at $650{ }^{\circ} \mathrm{C}$ presents the highest discharge specific capacity of $314.3 \mathrm{~mA} \mathrm{~h} \mathrm{~g}^{-1}$, demonstrating the best cycling performances.

Fig. 4(a) shows the comparison of cycling performance of $\mathrm{Co}_{3} \mathrm{O}_{4} @ \mathrm{CNFs}, \mathrm{Co}_{3} \mathrm{O}_{4} \mathrm{NFs}$ and CNFs at a rate of $50 \mathrm{~mA} \mathrm{~g}^{-1}$ in the

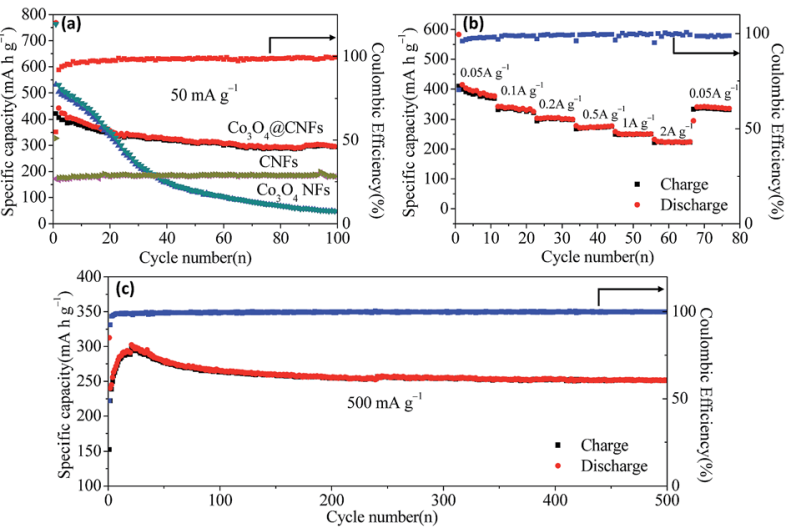

Fig. 4 (a) The cycling performance of $\mathrm{CO}_{3} \mathrm{O}_{4} @ \mathrm{CCNFs}$ (red), $\mathrm{CO}_{3} \mathrm{O}_{4} \mathrm{NFs}$ (green) and CNFs (yellow); (b) rate capability of the $\mathrm{CO}_{3} \mathrm{O}_{4} @ \mathrm{CNFs}$ at various current rates between $0.05 \mathrm{~A} \mathrm{~g}^{-1}$ to $2 \mathrm{~A} \mathrm{~g}^{-1}$; (c) high current cycling performance of $\mathrm{CO}_{3} \mathrm{O}_{4} \mathrm{QCNFs}$ at a current density of $500 \mathrm{~mA} \mathrm{~g}^{-1}$.

voltage range of $0.01-3.0 \mathrm{~V}$ (versus $\mathrm{Na}^{+} / \mathrm{Na}$ ) up to 100 cycles. The reversible capacity of $\mathrm{Co}_{3} \mathrm{O}_{4} @ \mathrm{CNFs}$ composite remains $\sim 300$

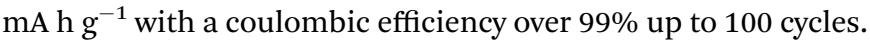
However, the reversible capacity of $\mathrm{Co}_{3} \mathrm{O}_{4} \mathrm{NFs}$ is only $46.9 \mathrm{~mA} \mathrm{~h}$ $\mathrm{g}^{-1}$ after 100 cycles. The much improved electrochemical performance of $\mathrm{Co}_{3} \mathrm{O}_{4}$ @CNFs may be attributed to the unique 1D structure with $\mathrm{Co}_{3} \mathrm{O}_{4}$ nanoparticles uniformly embedded in the carbon framework, enabling stable structural integrity to accommodate the volume change during the repeated cycling. The volume expansion of both the $\mathrm{Co}_{3} \mathrm{O}_{4} @ \mathrm{CNFs}$ and $\mathrm{Co}_{3} \mathrm{O}_{4} \mathrm{NFs}$ during the cycling process (before and after 50 cycles) were evaluated by the SEM imagine. As we can see from Fig. $\mathrm{S} 7, \uparrow$ the structure of $\mathrm{Co}_{3} \mathrm{O}_{4} @ \mathrm{CNFs}$ electrode after 50 cycles shows negligible changes, indicating the attractive morphological stability. In contrast, the cycled $\mathrm{Co}_{3} \mathrm{O}_{4}$ NFs electrode shows obvious collapse and aggregation, demonstrating that the carbon nanofibers can effectively relieve the volume expansion and guarantee the structure stability of the electrode.

Rate capability measurement was carried out on the $\mathrm{Co}_{3}$ $\mathrm{O}_{4} @ \mathrm{CNFs}$ composite cells at various current densities (Fig. 4(b)). The reversible capacity of $\mathrm{Co}_{3} \mathrm{O}_{4} @ \mathrm{CNFs}$ is $394.8 \mathrm{~mA} \mathrm{~h}$ $\mathrm{g}^{-1}$ at the current density of $50 \mathrm{~mA} \mathrm{~g}^{-1}$ for 10 cycles. When the current density was increased to $100,200,500,1000$ and 2000 $\mathrm{mA} \mathrm{g}^{-1}$, the corresponding capacity values are $343,305.5,278.1$, 258.5 and $225.1 \mathrm{~mA} \mathrm{~h} \mathrm{~g}^{-1}$, respectively. Moreover, the reversible capacity of $342.3 \mathrm{~mA} \mathrm{~h} \mathrm{~g}^{-1}$ can still be retained when the current density was returned to $50 \mathrm{~mA} \mathrm{g^{-1 }}$. Besides, the coulombic efficiency quickly increases to over $96 \%$ after the initial few cycles and remains stable in the subsequent cycles. This excellent rate capability can be ascribed to the improved electrical conductivity rendered by the carbon nanofiber framework, which is more convenient for electron transport. Moreover, the unique 1D nanofiber is favourable for the $\mathrm{Na}^{+}$insertion/ extraction, leading to fast interfacial charge transfer and $\mathrm{Na}^{+}$ diffusion in the composite materials.

In addition to the high rate capability, the $\mathrm{Co}_{3} \mathrm{O}_{4} @ \mathrm{CNFs}$ also exhibit superior long cycling performances. Fig. 4(c) shows the 
long-cycling stability of $\mathrm{Co}_{3} \mathrm{O}_{4} @ \mathrm{CNFs}$ at $500 \mathrm{~mA} \mathrm{~g}^{-1}$ over 500 cycles. The reversible capacity has been increasing during the initial 20 cycles and reaches the highest specific capacity value of $298.5 \mathrm{~mA} \mathrm{~h} \mathrm{~g}^{-1}$, which may be caused by the gradual activation of the composite materials in the first few cycles. After 500 cycles, the $\mathrm{Co}_{3} \mathrm{O}_{4} @ C N F s$ composite material still remains $251.7 \mathrm{~mA} \mathrm{~h} \mathrm{~g}^{-1}$ with a capacity retention of $84.3 \%$. In addition, the coulombic efficiency rapidly rises up to $99.6 \%$ in the subsequent cycles, indicating stable reversibility.

The electrochemical impedance spectroscopy (EIS) of $\mathrm{Co}_{3}$ $\mathrm{O}_{4} @ \mathrm{CNFs}$ and $\mathrm{Co}_{3} \mathrm{O}_{4}$ NFs were conducted to further confirm the mechanism of the electrochemical behavior. The Nyquist plots of $\mathrm{Co}_{3} \mathrm{O}_{4} @ \mathrm{CNFs}$ and $\mathrm{Co}_{3} \mathrm{O}_{4}$ NFs electrodes after 50 cycles as well as the equivalent circuit are presented in Fig. S8. $\dagger$ Apparently, the $\mathrm{Co}_{3} \mathrm{O}_{4} @ C N F s$ electrode exhibits much lower SEI film resistance $\left(R_{\mathrm{sf}}, 2.1 \Omega\right)$ and charge transfer resistance $\left(R_{\mathrm{ct}}\right.$, $41.4 \Omega$ ) than those of the $\mathrm{Co}_{3} \mathrm{O}_{4}$ NFs electrode $(3.4 \Omega$ and 223.4 $\Omega$ ) based on the equivalent circuit simulation, revealing the high electronic and ionic conductivity of the $\mathrm{Co}_{3} \mathrm{O}_{4} @$ @NFs electrodes, resulting in great enhancement in the rate capability and cycling stability.

\section{Conclusions}

A unique 1D structure of $\mathrm{Co}_{3} \mathrm{O}_{4} @$ @NFs composite has been synthesized by a facile, cost-effective and scalable electrospinning method and applied as anode materials of SIBs. Compared to the pure $\mathrm{Co}_{3} \mathrm{O}_{4}$ NFs, the $\mathrm{Co}_{3} \mathrm{O}_{4} @$ @NFs exhibit great enhancement in electrochemical performances of high reversible capacity of $422.4 \mathrm{~mA} \mathrm{~h} \mathrm{~g}^{-1}$ with good rate capability and cycling stability over 500 cycles. The outstanding electrochemical performances of $\mathrm{Co}_{3} \mathrm{O}_{4} @ \mathrm{CNFs}$ can be ascribed to the unique 1D structure with $\mathrm{Co}_{3} \mathrm{O}_{4}$ nanoparticles uniformly distributed in the carbon nanofiber frameworks. The 1D carbon nanofiber can not only increase the electronic and ionic conductivity of the composite electrodes, but also serve as a buffering matrix to accommodate the volume change and protect the composite electrode from pulverization during the repeated $\mathrm{Na}^{+}$insertion/extraction, enabling $\mathrm{Co}_{3} \mathrm{O}_{4} @ \mathrm{CNFs}$ to be promising anode materials for SIBs. Furthermore, the nanostructure design and synthesis described in this work may provide new insights for development of better host materials for practical energy storage applications.

\section{Acknowledgements}

This work was supported by the Natural Foundation of China (Grant 21503084, 51622703), 973 Program (2015CB258400) and the National Thousand Talents Program of China. The authors thank Analytical and Testing Center of HUST for XRD, SEM and FETEM measurements.

\section{Notes and references}

1 M. Winter and R. J. Brodd, Chem. Rev., 2004, 104, 4245-4270.

2 C. J. Barnhart and S. M. Benson, Energy Environ. Sci., 2013, 6, 1083.
3 A. L. Mohana Reddy, S. R. Gowda, M. M. Shaijumon and P. M. Ajayan, Adv. Mater., 2012, 24, 5045-5064.

4 J. B. Goodenough, Energy Environ. Sci., 2014, 7, 14-18.

5 N. S. Choi, Z. Chen, S. A. Freunberger, X. Ji, Y. K. Sun, K. Amine, G. Yushin, L. F. Nazar, J. Cho and P. G. Bruce, Angew. Chem., 2012, 51, 9994-10024.

6 M. D. Slater, D. Kim, E. Lee and C. S. Johnson, Adv. Funct. Mater., 2013, 23, 947-958.

7 B. L. Ellis and L. F. Nazar, Curr. Opin. Solid State Mater. Sci., 2012, 16, 168-177.

8 H. Pan, Y.-S. Hu and L. Chen, Energy Environ. Sci., 2013, 6, 2338.

9 C. Fang, Y. Huang, W. Zhang, J. Han, Z. Deng, Y. Cao and H. Yang, Adv. Energy Mater., 2016, 6, 1501727.

10 D. Kim, S.-H. Kang, M. Slater, S. Rood, J. T. Vaughey, N. Karan, M. Balasubramanian and C. S. Johnson, Adv. Energy Mater., 2011, 1, 333-336.

11 H. Kim, H. Kim, Z. Ding, M. H. Lee, K. Lim, G. Yoon and K. Kang, Adv. Energy Mater., 2016, 1600943, DOI: 10.1002/ aenm.201600943.

12 Q. Zhang, W. Wang, Y. Wang, P. Feng, K. Wang, S. Cheng and K. Jiang, Nano Energy, 2016, 20, 11-19.

13 M. Zhou, W. Li, T. Gu, K. Wang, S. Cheng and K. Jiang, Chem. Commun., 2015, 51, 14354-14356.

14 Y. You, X. Yu, Y. Yin, K.-W. Nam and Y.-G. Guo, Nano Res., 2014, 8, 117-128.

15 I. Hasa, R. Verrelli and J. Hassoun, Electrochim. Acta, 2015, 173, 613-618.

16 Z. L. Brown, S. Smith and M. N. Obrovac, J. Electrochem. Soc., 2014, 162, A15-A20.

17 Y. Jiang, M. Hu, D. Zhang, T. Yuan, W. Sun, B. Xu and M. Yan, Nano Energy, 2014, 5, 60-66.

18 Z. Jian, B. Zhao, P. Liu, F. Li, M. Zheng, M. Chen, Y. Shi and H. Zhou, Chem. Commun., 2014, 50, 1215-1217.

19 X. Liu, T. Chen, H. Chu, L. Niu, Z. Sun, L. Pan and C. Q. Sun, Electrochim. Acta, 2015, 166, 12-16.

20 F. Zou, Y. M. Chen, K. Liu, Z. Yu, W. Liang, S. M. Bhaway, M. Gao and Y. Zhu, ACS Nano, 2016, 10, 377-386.

21 Y. Lu, N. Zhang, Q. Zhao, J. Liang and J. Chen, Nanoscale, 2015, 7, 2770-2776.

22 Z. Jian, P. Liu, F. Li, M. Chen and H. Zhou, J. Mater. Chem. A, 2014, 2, 13805.

23 Y. Liu, Z. Cheng, H. Sun, H. Arandiyan, J. Li and M. Ahmad, J. Power Sources, 2015, 273, 878-884.

24 C. T. Cherian, J. Sundaramurthy, M. Kalaivani, P. Ragupathy, P. S. Kumar, V. Thavasi, M. V. Reddy, C. H. Sow, S. G. Mhaisalkar, S. Ramakrishna and B. V. R. Chowdari, J. Mater. Chem., 2012, 22, 12198.

25 X. Zhang, H. Liu, S. Petnikota, S. Ramakrishna and H. J. Fan, J. Mater. Chem. A, 2014, 2, 10835.

26 S. Abouali, M. Akbari Garakani, B. Zhang, H. Luo, Z.-L. Xu, J.-Q. Huang, J. Huang and J.-K. Kim, J. Mater. Chem. A, 2014, 2, 16939-16944.

27 T. Y. Ma, S. Dai, M. Jaroniec and S. Z. Qiao, J. Am. Chem. Soc., 2014, 136, 13925-13931.

28 S. Abouali, M. A. Garakani, B. Zhang, Z. L. Xu, E. K. Heidari, J. Q. Huang, J. Huang and J. K. Kim, ACS Appl. Mater. Interfaces, 2015, 7, 13503-13511. 